on the constitution and state of the upper atmosphere. The study of the spectra of gases at low temperature enabled the first experimental proof of the existence of para- and ortho-hydrogen to be established. The Raman effect with liquid gases such as oxygen, hydrogen, and nitrogen has been investigated and the crystal structure of solidified gases examined. At the present time two promising lines of research are in progress. One has to do with the evaluation of spin moments of atomic nuclei deduced from a study of the fine structure of spectral lines. The other is a continuation of a series of investigations on the superconductivity of elements and alloys. It has been found that the superconducting critical temperature is progressively lowered when currents of increasing frequency are used. This opens up an entirely new line of attack upon the problem of superconductivity.

\section{Early Knowledge of Iron in the Pacific.}

Mr. T. A. RickarD's communication on "The Knowledge and Use of Iron among the South Sea Islanders", read before the Royal Anthropological Institute on Jan. 12, offered what may be regarded as a highly probable explanation of the fact noted by early navigators, that while the inhabitants of some of the islands showed themselves eager to obtain iron, in other islands they were indifferent. It is recorded, for example, by Wallis, Cook, and others that in the Sandwich Islands, Tonga, and Tahiti the natives were prepared to go to any lengths to get iron, whereas in New Zealand and the New Hebrides they showed no such desire. Mr. Rickard finds the clue to the explanation of this difference in statements in Mindana, a Spanish explorer, who in 1567 saw " a chisel made into a nail" in the Marshall Islands, and of a native historian of Hawaii, who in 1867 said that the Hawaiians recognised iron on Cook's ship because they "had found iron in sticks washed up on the land ". Thus iron would appear to have become known in various parts of the Pacific through having been washed up in driftwood. The effect of drift in the distribution of culture in the Pacific is a subject which stands in need of closer investigation, especially in relation to the various theories of culture-distribution in that area which have been put forward. Drift has been suggested, for example, as probably an element entering into the distribution of the coconut, and some years ago the late Sir Henry Howorth was inclined to think that the adoption of red as the royal colour in Hawaii and other parts of the Pacific might have been derived from the use of that colour by the Buddhists in China and Tibet, and carried thence to the Pacific by Chinese junks which had drifted, or been driven, out of their course.

\section{Glacial Man in America.}

The Division of Anthropology and Psychology of the National Research Council of the United States of America, which, by its scheme of organised co. operation throughout the middle west, is doing much to ensure the recording and preservation of objects of archæological interest already known or casually dis- covered, as well as to promote research, has now directed attention to the possibility of obtaining evidence relating to the existence of glacial man in America from casual or commercial excavation, especially in centres where there is evidence of glacia. tion. American anthropologists have been much impressed by the frequency with which relics of pre. historic man have been unearthed in Europe in the course of commercial excavation, to which the attention of the expert has been attracted, or on which the workmen have been warned to be on the look-out for anything of an unusual character.

IT is a well-known fact that the evidential value of a number of archæological finds in America, for which a special significance in prehistory has been claimed, has been vitiated by the lack of trustworthy corroboratory geological and other data. The Division of Anthropology is accordingly attempting to arouse interest in such discoveries, and to disseminate knowledge of the data required by science in relation to any chance find which may be brought to light in the course of the extensive excavations by commercial undertakings, such, for example, as the railways, in various parts of America. A conference of the leading archæologists of the United States and representative engineers was held at Chicago in April last for the discussion of this matter, and a report has now been issued by the Council (Reprint and Circular Series No. 100). The conference adopted a scheme of co-operative research, and a number of directions were prepared to be issued in leaflet form to bodies excavating in areas where evidence of glacial man is likely to occur.

\section{Multi-Channel Television.}

ONE of the difficulties met in designing a new system of television is the narrowness of the frequeney band of the waves permissible when only one channel of transmission is used. At the Institution of Electrical Engineers on Jan. 6, C. O. Browne showed how this difficulty can be largely overcome by using a number of transmission channels. By using five channels, the frequency band is increased five times and the difficulties of design are greatly diminished. In addition, the velocity with which the scanning spots travel over the surface of the picture is deereased and the difficulties of good synchronisation are largely obviated. To get a moderately good picture, experience shows that the picture should consist of 15,000 picture points at least, and the picture must be scanned about $12 \frac{1}{2}$ times per second. This number was chosen because the standard frequency of the supply mains in Great Britain is 50. With small screens, satisfactory results are obtained, but when a ground glass screen measuring 24 in. $\times 16$ in. is used there is a decrease in the brilliance of the received image. With the large received picture, the effect of flicker is pronounced and a higher scanning speed than $12 \frac{1}{2}$ pictures per second needs to be used. The author has investigated the best conditions for operating the Kerr cells used in the receiver, and discusses the effects produced by geometric, nonlinear, and frequency distortion.

No. 3247, VoL. 129] 